balamin, and when given along with sodium nitroprusside reduces erythrocyte and plasma cyanide concentrations and prevents the occurrence of lactic acidosis. ${ }^{17}$ Sodium thiosulphate has several advantages: it is of low toxicity, is an antidote in its own right by acting as sulphur donor for rhodanese, and enhances the antidotal efficacy of hydroxocobalamin. ${ }^{20}$ Since hydroxocobalamin has a short plasma half life when used prophylactically it should be given by continuous intravenous infusion during the period of infusion of sodium nitroprusside with periodic separate injections of sodium thiosulphate. For treating established poisoning the two substances should be given separately, allowing an interval of about one minute between injections, ${ }^{20}$ because of the possible formation of an inactive complex if they are mixed before injection. Amyl nitrite capsules should be available for the prompt treatment of established acute cyanide poisoning, and oxygen is valuable in enhancing the effect of cyanide antidotes. ${ }^{21}$ Bicarbonate infusions may be needed to treat lactic acidosis.

1 Tinker, J H, and Michenfelder, J D, Anesthesiology, 1976, 45, 340.

2 Ziesche, S, and Franciosa, J A, Heart and Lung, 1977, 6, 99.

3 O'Dell, C W, et al, Radiology, 1977, 124, 73.

Greiss, L, Tremblay, N A, and Davies, D W, Canadian Anaesthetists' Society fournal, 1976, 23, 480.

${ }^{5}$ Posner, M A, et al, Anesthesia and Analgesia, 1977, 56, 729.

6 Vesey, C J, et al, British Medical fournal, 1974, 2, 140.

7 Smith, R P, and Kruszyna, H, Fournal of Pharmacology and Experimental Therapeutics, 1974, 191, 557 .

8 Vesey, C J, Cole, P V, and Simpson, P J, British fournal of Anaesthesia, 1977, 49, 395.

9 Vesey, C J, and Wilson, J, fournal of Pharmacy and Pharmacology, 1978, 30, 20.

${ }^{10}$ Ballantyne, B, fournal of the Forensic Science Society, 1975, 15, 51

11 Davies, D W, et al, Canadian Anaesthetists' Society fournal, 1975, 22, 547.

12 Ballantyne, B, in Forensic Toxicology, ed B Ballantyne. Bristol, Wright, 1974.

${ }^{13}$ Vesey, C J, Cole, P V, and Simpson, P J, British fournal of Anaesthesia, 1976, 48, 651 .

14 Ballantyne, B, Clinical Toxicology, 1977, 11, 195

15 Vesey, C J, Cole, P V, and Simpson, P J, British Medical fournal, 1975, 3, 229

16 Mookheriee, S, et al, Chest, 1977, 72, 273.

17 Cottrell, J E, et al, New England fournal of Medicine, 1978, 298, 809.

18 DuClair, J, et al, Annales de l'Anesthésiologie Française, 1976, 17, 519.

19 Bennett, N R, and Abbott, T R, Anaesthesia, 1977, 32, 456.

20 Friedberg, K D, and Shukla, U R, Archives of Toxicology, 1975, 33, 108

${ }^{21}$ Sheehy, M, and Way, J L, fournal of Pharmacology and Experimental Therapeutics, 1968, 161, 163.

\section{Treatment of childhood cancer: effects on the gonads}

Treatment of childhood cancer with surgery, radiotherapy, and chemotherapy has already resulted in the long-term survival of several thousand children in Britain alone. Cure of malignant disease with these methods in such young patients means that they have most of their life spans still to run so that there is a proportionately greater chance for any long-term damage to normal organs and tissues to emerge.

The gonads are a case in point. Increasingly successful use of high radiation doses and cytotoxic drug combinations has made questions about reproductive capacity and mutagenic effects relevant. The results of recent studies of pubertal and prepubertal children have shown serious histological changes ${ }^{1} 2$ and hormonal disturbances ${ }^{3} 4$ from both radiotherapy and chemotherapy. The different patterns of development of the ovaries and testes suggest that these effects may be different in the two sexes and may be critically dependent on age.
The preliminary stages of oogenesis are complete by 6 months of life, ${ }^{5}$ after which the oocytes are a fixed cell population. Ovarian follicles grow and degenerate throughout childhood, ${ }^{6}$ but as plasma follicle-stimulating hormone (FSH) and oestrogen concentrations rise from 6 years onwards there is an associated increase in large follicles and granulosa cells. In contrast, the prepubertal testes are inactive, containing small seminiferous tubules in which only a few gonocytes are detectable. Between 10 and 14 years there is rapid proliferation to produce adult spermatocytes as well as androgen-producing Leydig cells under the influence of FSH. ${ }^{8}$ During this period the testis is particularly vulnerable, ${ }^{4}$ but before puberty it may be less susceptible to damage than the metabolically more active ovary.

In adults tumoricidal doses of pelvic irradiation normally produce gonadal failure shown by amenorrhoea and aspermia. ${ }^{910}$ The numbers of germ cells are reduced and there are fibrotic changes and a rise in the amounts of circulating FSH and luteinising hormone $(\mathrm{LH})$. Oestrogen concentrations fall in women, but in men androgen production is usually preserved $^{11}$ and impotence is not a complication.

Recent Danish necropsy studies ${ }^{12}$ have shown severe histological damage (reduced follicle growth and number of oocytes) in the ovaries of prepubertal girls given 2000-3000 rads abdominal irradiation. The combination of drugs and irradiation was particularly harmful. These effects correlate with the endocrine changes noted by Shalet et $a l^{3}$ in 18 girls given abdominal irradiation one to 26 years earlier (seven had also had chemotherapy). Ten of the 12 girls aged 13 or more had had no menarche, and two had secondary amenorrhoea. Serum LH and particularly FSH concentrations were high, and oestradiol concentrations were normal for the prepubertal stage, giving a picture similar to gonadal dysgenesis. ${ }^{12}$ Large mature follicles may be more vulnerable than primary follicles.

Chemotherapy alone may be less damaging. Cyclophosphamide damages the gonads in both adults ${ }^{13}$ and children ${ }^{14}$ but the effect is dose-related and may be reversible. ${ }^{1516}$ Again, both age and sex are important. Seven boys with nephrotic syndrome treated with cyclophosphamide during puberty later showed reduced spermatogenesis and raised circulating FSH concentrations, whereas 16 prepubertal boys had normal FSH concentrations and all 11 girls studied were normal. ${ }^{14} \mathrm{~A}$ retrospective study of 35 girls treated for acute leukaemia showed normal pubertal development and normal LH and FSH concentrations in $80 \%$, though six of 18 who started treatment during or after puberty were abnormal. ${ }^{17}$ Most had received prophylactic cranial irradiation ( $2400 \mathrm{rads}$ ), which may indirectly depress ovarian function via the hypothalamic pituitary axis. ${ }^{18}$

Sherins et $a l^{4}$ have highlighted the vulnerability of the pubertal testis in a study of 21 Ugandan boys treated with quadruple chemotherapy for Hodgkin's disease. Nine of 19 survivors (all aged 11 or more when diagnosed) developed gynaecomastia a median of 28 months after treatment and had grossly raised FSH and LH and lowered testosterone concentrations indicating failure of the Leydig cells.

What of the mutagenic effects of radiotherapy and chemotherapy on the developing gonad ? If children cured of cancer reach adult life and marry, what are the hazards to the offspring? Results of studies so far are reassuring. Holmes and Holmes ${ }^{19}$ reported on 124 patients who had survived at least 10 years from the diagnosis of cancer in childhood. Sixty had married and 34 of these had produced 55 offspring. All the offspring were said to be in generally good health except one born of a parent with retinoblastoma, who had also developed 
retinoblastoma. $\mathrm{Li}$ and $\mathrm{Jaffe}^{20}$ reported on 46 patients who produced 107 pregnancies after treatment for malignant disease in childhood. There was no increase in abortions, stillbirths, cancer, or major chronic disease in the offspring. Possibly early death of an embryo might have passed unnoticed; recessive mutation would not be detectable in such a study.

We need long-term prospective studies of gonadal function and sexual development in children treated for cancer. The risk of permanent gonadal damage should be definable in both sexes in relation to the intensity of treatment and the age at the start. The collaborative follow-up study of childhood cancer survivors in Britain being organised by the Childhood Cancer Research Group ${ }^{21}$ should make such investigations easier to arrange.

${ }^{1}$ Himelstein-Braw, R, Peters, H, and Faber, M, British fournal of Cancer, $1977,36,269$.

${ }^{2}$ Himelstein-Braw, R, Peters, H, and Faber, M, Acta Radiologica (Therapy), 1978 , in press.

3 Shalet, S M, et al, British fournal of Cancer, 1976, 33, 655.

${ }^{4}$ Sherins, R J, Olweny, C L M, and Ziegler, J L, New England fournal of Medicine, 1978, 299, 12.

5 Lintern-Moore, S, et al, fournal of Reproduction and Fertility, 1974, 39, 53.

6 Valdes-Dapena, M, Annals of the New York Academy of Sciences, 1967, 142, 597.

${ }^{7}$ Peters, H, Himelstein-Braw, R, and Faber, M, Acta Endocrinologica, $1976,82,617$

${ }^{8}$ Ham, A W, Histology, 7th edn, p 904. London, Philadelphia, Lippincott, 1974

9 Baker, J W, et al, Lancet, 1972, 1, 1307.

10 Speiser, B, Rubin, P, and Casarett, G, Cancer, 1973, 32, 692.

11 Slanina, T, et al, International fournal of Radiation Oncology, Biology and Physics, 1977, 2, 1.

12 Penny, R, et al, fournal of Clinical Investigation, 1970, 49, 1847.

13 Fairley, K F, Barrie, J U, and Johnson, W, Lancet, 1972, 1, 568.

14 Pennisi, A J, Grushkin, C M, and Lieberman, E, American fournal of Diseases of Children, 1975, 129, 315.

15 Kumar, R, et al, Lancet, 1972, 1, 1212

${ }_{16}$ Buchanan, J D, Fairley, K F, and Barrie, J U, Lancet, 1975, 2, 156.

17 Siris, E S, Leventhal, B G, and Vaitukaitis, J L, New England fournal of Medicine, 1976, 294, 1143.

18 Shalet, S M, et al, fournal of Pediatrics, 1977, 90, 920.

19 Holmes, H A, and Holmes, F F, Clinical Pediatrics, 1975, 14, 819

$20 \mathrm{Li}, \mathrm{F} \mathrm{P}$, and Jaffe, N, Lancet, 1974, 2, 707.

${ }^{21}$ Draper, G L, 1978, personal communication.

\section{Spasmodic torticollis}

"Torticollis," said Kinnier Wilson," "is a mere symptom, and self-evident at that; the term denotes intermittent spasmodic movements of the neck muscles, also tonic attitudes of rotation or tilt." The spasms are either tonic or clonic and are caused by contractions, singly or in combination, of the sternomastoids, trapezii, and splenius capitis. In the nineteenth century Gowers ${ }^{2}$ recognised the occasional case where torticollis spread to facial and arm muscles and noted aching or "neuralgic" pain in severe forms and the hypertrophy of the affected muscles developing from overuse. The condition causes much distress, but medical progress has been disappointing.

It is important-and usually easy-to exclude torticollis secondary to cervical adenitis or other local painful conditions and to recognise torticollis tic, a variant of habit spasm. Despite much controversy, ${ }^{3}$ undoubtedly both hysterical and organic varieties of torticollis occur, but the latter now seems much more common. There are, however, two separate pitfalls-dogmatically ascribing all cases to a restricted localised form of torsion dystonia (dystonia musculorum deformans) and labelling all cases hysterical simply because pathological lesions in the brain are usually absent. Spasmodic torticollis occurred alone or with Parkinsonism in some cases of encephalitis lethargica. Yet good pathological studies have been rare and the best one ${ }^{4}$ found no macroscopic or histological abnormalities. Three earlier reports described bilateral lesions in the putamen, caudate, and pallidum, but their meaning is questionable. ${ }^{4}$ Lesions in the vestibular pathways induce abnormal tonic neck postures in macaques and other primates; lesions in and close to the red nucleus also cause tonic torticollis. ${ }^{5}$ But in man neither section of the eighth nerve nor labyrinthectomy appears to reproduce the clinical disorder. ${ }^{4}$

In a recent study Matthews $\mathrm{et}^{a l^{6}}$ have carefully studied and followed up 30 patients with torticollis. As in other series, women outnumbered men; the peak age of onset was in the fourth and fifth decades; and six patients had additional neurological signs (arm dystonia, writer's cramp, generalised torsion dystonia, essential tremor, and Parkinson's disease). The results of their investigations were essentially negative: electromyographic studies of neck muscle showed variable, inconsistent reflex effects on the spasms when the patient held weights in either hand, closed his eyes, and touched or pressed his face to restrain the movement (antagonistic gesture). Neuro-otological tests showed no vestibular dysfunction. Psychological assessment suggested no deviation from normal in personality before the torticollis developed; but the patients feared ridicule, had marital discord, and were made unhappy by their condition.

The usual natural history ${ }^{7}$ is that the condition progresses for five years, with a chance of remission, and is static for the next five years, with a final stage of late relapse or slow adjustment. In the Oxford series only six of 30 patients had early remissions and four of these later relapsed.

The various medical remedies have in common only their uselessness. Psychotherapy, ECT, phenothiazines, antidepressants, levodopa, and anticholinergics have been tried. Diazepam or haloperidol has given partial relief. These results tend to confirm the organic nature of the disease in most patients, but "cures" and occasional remissions of over 20 years produced by psychotherapy probably underline the conclusion that a few cases have a hysterical origin. Bilateral stereotactic surgery of the thalamus has produced occasional successes, but the results of most such operations have been disappointing. ${ }^{8}$ Anterior cervical rhizotomy, with division of the appropriate spinal accessory nerve, produced satisfactory results in some cases, ${ }^{9}$ but again there were late relapses. Indeed, despite all the recent attempts to clarify its causation and to find suitable treatment, established torticollis still poses intractable problems.

1 Wilson, S A K, Neurology, vol 2, p 1664. London, Arnold, 1940.

2 Gowers, W R, A Manual of Diseases of the Nervous System, vol 2, p 609. London, Churchill, 1888.

${ }^{3}$ Marsden, C D, and Harrison, M J G, Brain, 1974, 97, 793.

4 Tarlov, E, fournal of Neurology, Neurosurgery, and Psychiatry, 1970, 33, 457.

5 Denny-Brown, D, Proceedings of the Royal Society of Medicine, 1962, 55, 527.

${ }^{6}$ Matthews, W B, et al, fournal of Neurology, Neurosurgery, and Psychiatry, $1978,41,485$.

7 Meares, R, Lancet, 1971, 2, 149.

${ }^{8}$ Hankinson, J, in Recent Advances in Neurology and Neuropsychiatry, 8th edn, ed Lord Brain and M Wilkinson, p 147. London, Churchill, 1969.

${ }^{9}$ Northfield, D W C, The Surgery of the Central Nervous System, p 644. Oxford, Blackwell, 1973. 